\title{
Superiority index based on target traits reveals the evolution of Brazilian soybean cultivars over last half-century ${ }^{1}$
}

\author{
Matheus Henrique Todeschini², Leomar Guilherme Woyann², Anderson Simionato Milioli', \\ Daniela Meira ${ }^{2}$,Laura Alexandra Madella², Giovani Benin ${ }^{2} * \mathbb{0}$
}

10.1590/0034-737X202168040012

\begin{abstract}
The objective of this work was to assess the breeding influences in different agronomic and physiological traits in Brazilian soybean cultivars, released between 1965 and 2011, to identify traits associated with modern cultivars. A total of 29 cultivars were evaluated in two locations in the 2016/17 crop season. Genotype selection based on agronomic and physiological traits was determined using GYT (Grain Yield*Trait) methodology, which uses the Superiority Index to rank genotypes by mean of all traits. Grain Yield is combined with other target traits and shows the strengths and weaknesses of each genotype. Soybean breeding improved desirable traits during the 46 years of evaluation. Superiority index can be a powerful tool for breeders to obtain high genetic gains in the future. The cultivars DMario 58i, TMG 7161RR and TMG 7262 RR stand out as the best cultivars but present different sets of desirable traits. The traits grain yield, harvest index, number of pods per plant, reproductive-vegetative ratio, photosynthetic rate and transpiration rate are core traits which can be evaluated in soybean breeding programs.
\end{abstract}

Keywords: genotype selection; grain yield*trait biplot; multi-traits.

\section{INTRODUCTION}

Simultaneous selection for multi-traits is one of the key points for continuous genetic gain in soybean [Glycine $\max (\mathrm{L}$.) Merrill] breeding (Yan \& Frégeau-Reid, 2008). The simultaneous improvement of agronomic and physiological traits and the selection by performance indexes can be a useful strategy to identify genotypes closer to ideotype (Cruz et al., 2012). In this way, predict genetic gains to each trait have a great importance to indicate to breeder choices, and focus on the main desirable traits (Paula et al., 2002).

A selection index is a method of artificial plant selection to many traits simultaneously. It's based on the linear combination between traits, allowing adjustment of multiple traits in a single variable. This index is composed by a weight for each trait, and a truncation point for each trait must be established a priori by the breeder (Yan \& Frégeau-Reid, 2008).
For most crops with agronomic importance, the main target trait is grain yield (GY). However, a good performance in other traits in soybean crop is essential for release a new cultivar. Among these traits can be cited the life cycle, plant height, disease resistance and lodging resistance (Yan \& Frégeau-Reid, 2008). Nevertheless, these traits are important only when associated with GY (Zhang et al., 2015; Sharifi \& Ebadi, 2018).

Genotype by grain yield*trait (GYT) methodology, proposed by Yan \& Frégeau-Reid (2008), provide a Superiority Index (SI) which allows to evaluate genotypes in relation to multi-trait. Initially, each trait positively or negatively associated with the GY (main trait for soybean) is evaluated by the breeder for the correct decision to select the best genotype. The breeder has the responsibility for identifying if a trait is positively or negatively associated with GY, i.e., identify if GY should be multiplied or be divided by a specific trait. From this,

\footnotetext{
Submitted on August $3^{\text {rd }}, 2020$ and accepted on January $7^{\text {th }}, 2021$.

${ }^{1}$ This work is part of the first author's Master Dissertation.

${ }^{2}$ Universidade Tecnológica Federal do Paraná, Pato Branco, Paraná, Brazil, matheus_todeschini@hotmail.com, leowoyann@gmail.com, milioli.utfpr@gmail.com, dmdanielameira94@gmail.com, laura-madella12@hotmail.com, benin@utfpr.edu.br

*Corresponding author: benin @utfpr.edu.br
} 
indices are generated by multiplying the GY by the magnitudes of traits in question (positive selection) or by dividing the magnitude of traits by the GY (negative selection). This methodology uses GGE biplot analysis to verify the genotypes performance and to identify strengths and weaknesses of each genotype. The Superiority Index (SI) ranks genotypes by the mean of all traits.

Soybean genetic progress has been reported by innumerous studies. Therefore, the most of them highlighted the grain yield gains, and someone showed the agronomic and physiologic trait evolution, regardless to individual trait (Rogers et al., 2014; Zhang et al., 2015; Todeschini et al., 2019). Use the multi-traits indexes to quantify genetic gains could improve the acknowledgment about the relationship between traits and the main trait - grain yield - over the years. Thus, the objectives of this work were to assess the influence of soybean breeding in different agronomic and physiological traits of genotypes released between 1965 and 2011, and to identify traits associated to grain yield in the modern soybean genotypes.

\section{MATERIAL AND METHODS}

\section{Conduction of experiments}

The experiments were conducted in two locations in Brazil: Pato Branco-PR (26 ${ }^{\circ} 13^{`} \mathrm{~S}, 52^{\circ} 40^{`} \mathrm{~W}, 765 \mathrm{~m}$ a.s.1.) and Realeza-PR (25 $46^{\circ} \mathrm{S}, 53^{\circ} 32^{\circ} \mathrm{W}, 520 \mathrm{~m}$ a.s.1.), in the 2016/17 crop season. The soil of both locations is classified as a Hapludox (Santos et al. 2013), and the climate, according to the Koppen classification, is a Cfb type, humid subtropical with temperate summer (Alvares et al., 2013).

Twenty-nine soybean genotypes, available for cultivation in Brazil between 1965 and 2011 (Table 1), were evaluated. Experiments were conducted in a randomized complete block design, with three replications. The sowing density was 35 plants $\mathrm{m}^{-2}$. The experimental units consisted of four $5 \mathrm{~m}$ rows, spaced $0.5 \mathrm{~m}$ between rows. The two central rows of each plot, totaling $5 \mathrm{~m}^{2}$, were considered as useful area. Cultural practices were carried out according to the technical recommendations for soybean crop (Oliveira \& Rosa, 2014).

\section{Agronomic traits}

Grain yield (GY) was obtained from harvest of two central rows of each plot, totalizing $5 \mathrm{~m}^{2}$. The grain moisture was corrected to $130 \mathrm{~g} \mathrm{~kg}^{-1}$, and after that the GY was converted to $\mathrm{kg} \mathrm{ha}^{-1}$. In full maturity (R8) Fehr \& Caviness (1977), 15 plants per plot were randomly collected and the following traits were evaluated: plant height $(\mathrm{PH})$, measured in $\mathrm{cm}$, from the soil to last pod of plant; first pod height (FPH), measured in $\mathrm{cm}$, from the soil to first pod of plant; number of nodes per plant (NNP), obtained from counting of number of reproductive nodes of collected plants, and calculated average value; number of pods per plant (NPP), obtained from counting the number of pods per sampled plants, and calculating the average value; number of grain per pod (NGP), obtained from division between the number of grain and the number of pods of sampled plants. Biological yield (BY) was obtained by weighing the shoot of 15 sampled plants at random in plot. Straw yield (SY) was determined from the difference between BY and GY. Harvest index (HI) was calculated as $\mathrm{HI}=\mathrm{GY} / \mathrm{BY}$.

During the crop development, phenological traits of data of emergence (VE), beginning flowering (R1), and complete maturation (R8) were evaluated in both locations as described by (Fehr \& Caviness, 1977). Days to flowering (DTF) and days to maturity (DTM) were calculated by the number of days between VE and R1 stages, and between $\mathrm{VE}$ and $\mathrm{R} 8$ stages, respectively. The reproductive period, days flowering-maturation (DFM), was calculated as DFM $=\mathrm{DTM}-\mathrm{DTF}$. The ratio between reproductive $(\mathrm{R})$ and vegetative $(\mathrm{V})$ period $(\mathrm{R} / \mathrm{V})$ was calculated as $\mathrm{R} / \mathrm{V}=\mathrm{DFM} /$ DTF. Lodging was measured by visual evaluation, assigning a score from 1 to 9 . In this scale, the grade 1 was attributed to the fully erect genotype and 9 to the fully lodging.

\section{Physiological traits}

Photosynthetic traits were evaluated between 9:00 to 11:00 h in sunny days, at beginning of grain filling stage (R5) Fehr \& Caviness (1977), where the highest production of photoassimilates is required by plant. It was used a portable open system equipped with an infrared gas analyzer model LI-6400XT (LI-COR, Lincoln, Nebraska, USA), with automatic $\mathrm{CO}_{2}$ injector, and artificial red and blue light sources. The evaluated traits were: photosynthetic rate $\left(\mathrm{P}_{\mathrm{N}}, \mu \mathrm{mol} \mathrm{CO} \mathrm{m}^{-2} \mathrm{~s}^{-1}\right)$, stomatal

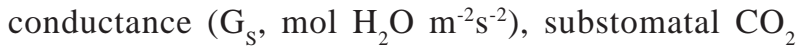
concentration $\left(\mathrm{C}_{\mathrm{I}}, \mathrm{mol} \mathrm{H}_{2} \mathrm{O} \mathrm{m}^{-2} \mathrm{~s}^{-2}\right)$, transpiration rate $(E$, mmol m $\mathrm{m}^{-2} \mathrm{~s}^{-1}$, and water use efficiency (WUE, \%), obtained by the ratio $\mathrm{P}_{\mathrm{N}}$ and $E$. The microclimatic conditions in the sample measurement chamber were adjusted at a constant rate with $200 \mu \mathrm{mol} \mathrm{m} \mathrm{s}^{-1}$ of PAR (Photosynthetic Active Radiation), and $400 \mathrm{ppm}$ of $\mathrm{CO}_{2}$, with a relative humidity between 50 e $80 \%$.

The individual indices of chlorophyll A (Chl.A) and B (Chl.B), and total chlorophyll (Chl.A + B) were measured at the $\mathrm{R} 1$ stage. The readings were performed on fully expanded leaves, in the upper third of plants, in 15 plants per experimental unit. The readings were performed with an electronic chlorophyll apparatus, model ClorofiLOG CFL 1030 (Falker, Porto Alegre, Brazil). 


\section{Statistical analysis}

The GYT was generated by the combination of each trait and GY, overall mean for each trait. The methodology developed by Yan \& Frégeau-Reid (2008) indicates that each trait should be multiplied or divided by GY according the objectives of the breeder. FPH and PH are two traits where an intermediate ideal value is required, where very high or very low values are not desirable. FPH should be sufficiently high to allow mechanic harvest and sufficiently low to express ideal NNP. PH should be sufficiently high to plant have the maximum NNP, but sufficiently short to avoid lodging. Thus, the values of $0.125 \mathrm{~m}$ and $1.00 \mathrm{~m}$ were attribute for FPH and PH, respectively. In this way, the closer to this value the more desirable it is. The GYT biplot permits the selection for all traits combined in a different way with GY. GY values was multiplied by BY, NNP, HI, DFM, R/V, TGW, NGP, WUE, $\mathrm{P}_{\mathrm{N}}, \mathrm{G}_{\mathrm{S}}, \mathrm{C}_{\mathrm{I}}, E$, Chl.A, Chl.B and Chl.A+B, where increase these traits together to GY is expected. In the other hand, GY was divided by
SY, Lod, DTF and DTM. For FPH and PH, GYT values were calculated by the follow equation: $G Y T=\frac{G Y}{(O v-I v)+1}$, where GYT is the index response for a specific trait; GY is the data for genotype $i$, across environments and replicates; $O v$ is the observed value for a specific trait; $I v$ is the ideal value for a specific trait; and 1 is a correction factor to standard GYT when $O v=I v$.

The mean and stability biplot had SVP $=1$ and is genotype-focused. The line with a single arrow (ATA) pass by biplot origin and point to high values of traits. The small circle indicates the "average yield-trait combination". Genotype projection vectors in relation to ATC (double-arrow line) indicates if a genotype had an all-rounded or balanced trait profile. Genotypes closer to ATA (without projections in the direction of ATC) are more desirable because have balanced trait profiles (Yan \& Frégeau-Reid, 2008). Analyses were performed using GGEbiplot software (Yan, 2001).

Table 1: Brazilian soybean cultivars evaluated for grain yield, agronomic and physiological traits, in two locations in the 2016/17 crop season

\begin{tabular}{|c|c|c|c|c|c|}
\hline Code & Genotype & $\begin{array}{l}\text { Breeding } \\
\text { Company }\end{array}$ & $\begin{array}{c}\text { Year } \\
\text { of Release }\end{array}$ & $\begin{array}{c}\text { Modern }(\mathbf{M}) \\
\text { or Old }(\mathbf{O})\end{array}$ & $\begin{array}{c}\text { Conventional } \\
(\mathrm{CV}) \text { or } \mathbf{R} \mathbf{R}^{(1)}\end{array}$ \\
\hline $\bar{M} 1$ & DMario $58 \mathrm{i}$ & GDM Seeds & 2007 & $\mathrm{M}$ & RR \\
\hline M2 & Dmario 70i & GDM Seeds & 2007 & M & RR \\
\hline M3 & BMX Potência RR & GDM Seeds & 2007 & M & RR \\
\hline M4 & BMX Titan RR & GDM Seeds & 2007 & M & RR \\
\hline O5 & BR 16 & Embrapa & 1987 & $\mathrm{O}$ & $\mathrm{CV}$ \\
\hline O6 & BR 4 & Embrapa & 1979 & $\mathrm{O}$ & $\mathrm{CV}$ \\
\hline $\mathrm{O} 7$ & Bragg & Embrapa (PI) ${ }^{(2)}$ & 1966 & $\mathrm{O}$ & $\mathrm{CV}$ \\
\hline O8 & BRS 133 & Embrapa & 1997 & $\mathrm{O}$ & $\mathrm{CV}$ \\
\hline O9 & BRS 184 & Embrapa & 2001 & $\mathrm{O}$ & $\mathrm{CV}$ \\
\hline M10 & BRS 232 & Embrapa & 2003 & M & $\mathrm{CV}$ \\
\hline M11 & BRS 284 & Embrapa & 2009 & M & $\mathrm{CV}$ \\
\hline $\mathrm{O} 12$ & CD 202 & Coodetec & 1998 & $\mathrm{O}$ & $\mathrm{CV}$ \\
\hline $\mathrm{O} 13$ & CD 206 & Coodetec & 1999 & $\mathrm{O}$ & $\mathrm{CV}$ \\
\hline $\mathrm{O} 14$ & CD 208 & Coodetec & 1999 & $\mathrm{O}$ & $\mathrm{CV}$ \\
\hline M15 & CD 214RR & Coodetec & 2003 & M & RR \\
\hline O16 & CD 215 & Coodetec & 2002 & $\mathrm{O}$ & $\mathrm{CV}$ \\
\hline $\mathrm{O} 17$ & Davis & Embrapa (PI) & 1965 & $\mathrm{O}$ & $\mathrm{CV}$ \\
\hline $\mathrm{O} 18$ & Embrapa 48 & Embrapa & 1995 & $\mathrm{O}$ & $\mathrm{CV}$ \\
\hline O19 & FT Abyara & FT Sementes & 1988 & $\mathrm{O}$ & $\mathrm{CV}$ \\
\hline $\mathrm{O} 20$ & IAS 5 & Embrapa & 1973 & $\mathrm{O}$ & $\mathrm{CV}$ \\
\hline $\mathrm{O} 21$ & OCEPAR 4 & Ocepar & 1987 & $\mathrm{O}$ & $\mathrm{CV}$ \\
\hline $\mathrm{O} 22$ & Paraná & Embrapa & 1974 & $\mathrm{O}$ & $\mathrm{CV}$ \\
\hline M23 & TMG 7161RR & $\mathrm{TMG}^{(3)}$ & 2010 & M & RR \\
\hline M24 & TMG 7262 RR & TMG & 2011 & M & RR \\
\hline M25 & NK 7059 RR & Syngenta & 2007 & M & RR \\
\hline M26 & SYN1059 RR & Syngenta & 2010 & M & $\mathrm{RR}$ \\
\hline M27 & NA 5909 RG & Syngenta & 2008 & M & RR \\
\hline $\mathrm{O} 28$ & Nova Bragg (BR 6) & Embrapa & 1981 & $\mathrm{O}$ & $\mathrm{CV}$ \\
\hline M29 & NS 4823 & Syngenta & 2008 & M & RR \\
\hline
\end{tabular}

${ }^{(1)}$ RR: RoundUp Ready® technology; ${ }^{(2)}$ PI: Plant Introduction. ${ }^{\left({ }^{3}\right.}$ TMG: TMG Tropical Melhoramento e Genética S.A. 
The Pearson's correlation analysis was performed for the original data of all evaluated traits using function correlation () in agricolae package (Mendiburu, 2017); and plotted using corrplot package, function corrplot (), in R software (http://www.R-project.org).

\section{RESULTS}

The which-won-where biplot (Figure 1) allows to identify genotypes with higher values for each combination (GY*Trait) in the respective sector. Genotype M1 present high values for SY, Lod, HI and DTF. M23 had high values for PH, FPH, NNP, BY and NPP. M24 had high values for R/ V, DTM, TGW, NGP, WUE, $\mathrm{P}_{\mathrm{N}}, \mathrm{G}_{\mathrm{S}}, \mathrm{C}_{\mathrm{I}}, E$, Chl.A, Chl.B and Chl.A+B. In this way, genotypes M24, M23, and M1 presented superior performance for different sets of traits. On the other hand, O17 and O6 do not have association with any $\mathrm{GY}^{*}$ Trait, indicating that they are not desirable.

The genotypes M24, M23 and M1 presented the highest mean values for SI (Table 2). Among these genotypes, of these, M1 had negative values for FPH and for $\mathrm{PH}$, indicating that this genotype had the best indexes;
M23 had negative values for SY, indicating that this genotype produces a high amount of straw. M24 had negative values for FPH, and reveled low indexes. The modern genotypes M24 (2011), M23 (2010) and M1 (2007) may be considered the best genotypes, each with specific positive $\mathrm{GY} *$ traits associations. In the other hand, old genotypes, i.e., O17 (1965) and O6 (1979), were the worst genotypes in GYT biplot (Figure 1). In addition, M15 (2003) is exactly the "average genotype" between old and modern genotypes, with a $\mathrm{SI}=0.00$.

Agreeing with (Figure 2), the best grain yield was verified to genotypes M24, M23 and M1 and the worst genotypes were $\mathrm{O} 17$ and O6. Genotype M15 ( $1^{\text {st }}$ genotype classified as a modern genotype) was the first genotype with RoundUp Ready ${ }^{\circledR}$ technology in the dataset. This genotype had a SI of 0.00 , indicating that M15 had intermediate values. Some old genotypes had positive SI, e.g., O16 and O9, and a modern genotype presented negative values for SI, e.g., M4. Nevertheless, the biggest part of modern genotypes had positive values for SI and old genotypes had negative values for SI.

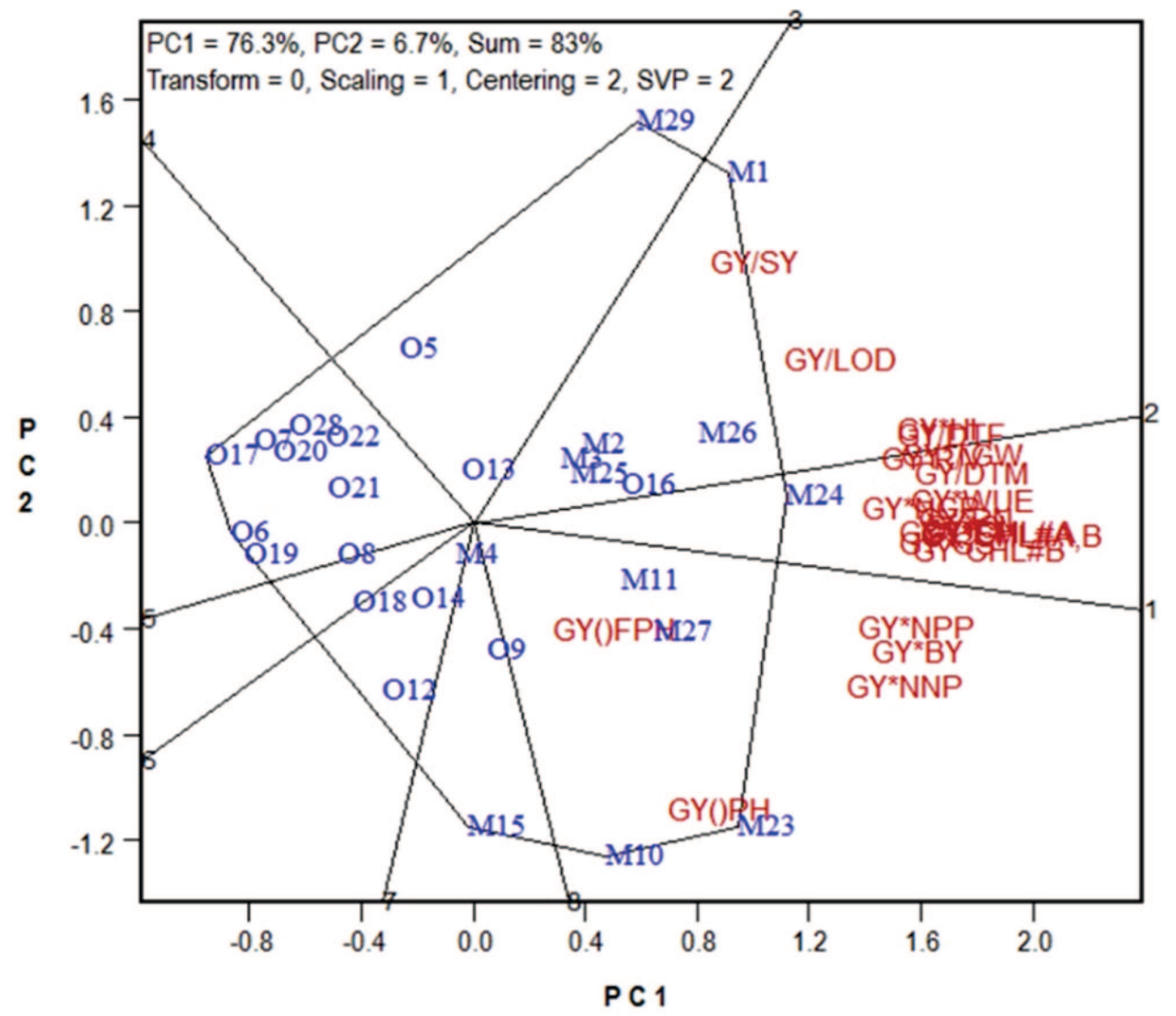

Figure 1: Which-Won-Where view of the genotype by grain yield*trait (GYT) biplot to highlight genotypes with outstanding profiles. The biplot was based on singular value decomposition of the standardized GYT table (Table 2) ("Scaling = 1, Centering = 2"). The trait-focused singular value partition ("SVP = 2") was used. Trait codes: GY: grain yield; BY: biological yield; SY: straw yield; FPH: first pod height; NNP: number nodes per plant; NPP: number of pods per plant; HI: harvest index; PH: plant height; LOD: lodging; DTF: days to flowering; DFM: days flowering-maturation; DTM: days to maturity; R/V: reproductive - vegetative ratio; TGW: thousand grain weight; NGP: number of grain per pod; WUE: water use efficiency; PN: photosynthetic rate; GS: stomatal conductance; CI: substomatal CO2 concentration; E: transpiration rate; Chl. A: chlorophyll A content; Chl. B: chlorophyll B content; Chl. A+B: chlorophyll A+B content. See Table 1 for a full description of genotypes. 
Table 2: Superiority index using Genotype by grain yield*trait (GYT) methodology for 29 Brazilian soybean cultivars released between 1965 and 2011 , evaluated for grain yield, agronomic and physiological traits in two locations in the 2016/17 crop season

\begin{tabular}{|c|c|c|c|c|c|c|c|c|c|c|c|c|}
\hline Genotype & $\begin{array}{c}\text { GY*1 } \\
\text { BY }\end{array}$ & $\begin{array}{l}\text { GY }()^{2} \\
\text { FPH }\end{array}$ & $\begin{array}{c}\text { GY } \beta \\
\text { SY }\end{array}$ & $\begin{array}{l}\text { GY* } \\
\text { NNP }\end{array}$ & $\begin{array}{l}\text { GY* } \\
\text { NPP }\end{array}$ & $\begin{array}{c}\text { GY* } \\
\text { HI }\end{array}$ & $\begin{array}{c}\text { GY( }) \\
\text { PH }\end{array}$ & $\begin{array}{c}\text { GY/ } \\
\text { LOD }\end{array}$ & $\begin{array}{c}\text { GY/ } \\
\text { DTF }\end{array}$ & $\begin{array}{c}\text { GY* } \\
\text { DFM }\end{array}$ & $\begin{array}{l}\text { GY* } \\
\text { R/V }\end{array}$ & $\begin{array}{c}\text { GY/ } \\
\text { DTM }\end{array}$ \\
\hline M1 & 0.61 & -0.17 & 2.11 & 0.40 & 0.70 & 1.83 & -0.79 & 1.80 & 1.80 & 1.31 & 1.62 & 1.68 \\
\hline M2 & 0.42 & 0.00 & 0.61 & 0.35 & 0.43 & 0.70 & -0.03 & 0.61 & 0.69 & 0.59 & 0.64 & 0.67 \\
\hline M3 & 0.50 & -0.53 & 0.22 & 0.27 & 0.42 & 0.57 & -0.11 & 0.52 & 0.56 & 0.54 & 0.57 & 0.51 \\
\hline M4 & 0.34 & -1.18 & -0.79 & -0.04 & 0.16 & -0.11 & -0.10 & -0.08 & -0.12 & 0.08 & 0.01 & -0.18 \\
\hline $\mathrm{O} 5$ & -0.80 & 0.01 & 0.58 & -0.75 & -0.68 & -0.19 & -0.83 & 0.08 & -0.20 & -0.48 & -0.27 & -0.29 \\
\hline O6 & -0.96 & -1.05 & -1.20 & -1.15 & -1.04 & -1.32 & -0.68 & -0.95 & -1.32 & -1.20 & -1.19 & -1.42 \\
\hline O7 & -1.07 & -1.04 & -0.72 & -1.26 & -1.10 & -1.08 & -0.99 & -0.65 & -1.09 & -1.12 & -1.00 & -1.22 \\
\hline $\mathrm{O} 8$ & -0.61 & -0.14 & -0.57 & -0.57 & -0.61 & -0.78 & -0.21 & -0.62 & -0.78 & -0.73 & -0.73 & -0.79 \\
\hline O9 & -0.26 & 2.21 & 0.56 & 0.45 & -0.02 & -0.13 & 0.92 & -0.36 & -0.11 & -0.16 & -0.25 & 0.10 \\
\hline M10 & 1.07 & 1.49 & -0.42 & 1.47 & 1.06 & 0.27 & 1.87 & -0.29 & 0.31 & 0.67 & 0.31 & 0.57 \\
\hline M11 & 0.85 & 0.32 & 0.26 & 0.85 & 0.81 & 0.72 & 0.63 & 0.45 & 0.73 & 0.81 & 0.71 & 0.80 \\
\hline $\mathrm{O} 12$ & -0.29 & 0.66 & -0.66 & -0.01 & -0.26 & -0.72 & 0.56 & -0.78 & -0.71 & -0.53 & -0.68 & -0.60 \\
\hline $\mathrm{O} 13$ & -0.06 & -0.40 & -0.01 & -0.18 & -0.08 & 0.01 & -0.28 & 0.09 & 0.01 & -0.03 & 0.02 & -0.04 \\
\hline O14 & -0.80 & 2.23 & 0.61 & -0.03 & -0.51 & -0.48 & 0.54 & -0.55 & -0.46 & -0.61 & -0.62 & -0.29 \\
\hline M15 & 0.57 & 0.43 & -1.16 & 0.70 & 0.46 & -0.42 & 1.25 & -0.72 & -0.39 & 0.03 & -0.29 & -0.23 \\
\hline O16 & 0.42 & 1.02 & 1.04 & 0.66 & 0.54 & 0.83 & 0.38 & 0.62 & 0.83 & 0.68 & 0.71 & 0.90 \\
\hline O17 & -1.44 & -0.51 & -0.64 & -1.43 & -1.39 & -1.36 & -0.96 & -0.91 & -1.37 & -1.45 & -1.32 & -1.47 \\
\hline O18 & -0.30 & -0.50 & -0.93 & -0.39 & -0.38 & -0.75 & -0.04 & -0.64 & -0.74 & -0.57 & -0.65 & -0.76 \\
\hline O19 & -0.92 & -0.74 & -1.11 & -1.02 & -0.98 & -1.27 & -0.51 & -0.96 & -1.27 & -1.16 & -1.16 & -1.34 \\
\hline $\mathrm{O} 20$ & -1.28 & 0.14 & -0.13 & -1.10 & -1.16 & -1.01 & -0.71 & -0.67 & -1.01 & -1.16 & -1.03 & -1.06 \\
\hline $\mathrm{O} 21$ & -0.62 & -0.80 & -0.63 & -0.79 & -0.67 & -0.74 & -0.59 & -0.48 & -0.75 & -0.72 & -0.67 & -0.83 \\
\hline $\mathrm{O} 22$ & -1.00 & 0.04 & 0.02 & -0.89 & -0.90 & -0.70 & -0.66 & -0.41 & -0.70 & -0.86 & -0.73 & -0.76 \\
\hline M23 & 2.15 & 0.00 & -0.70 & 1.97 & 1.89 & 1.05 & 1.81 & 0.39 & 1.07 & 1.59 & 1.19 & 1.25 \\
\hline M24 & 1.98 & -1.15 & 0.33 & 1.40 & 1.73 & 1.77 & 0.44 & 1.39 & 1.75 & 1.90 & 1.81 & 1.72 \\
\hline M25 & 0.79 & -1.26 & -0.17 & 0.31 & 0.60 & 0.62 & -0.16 & 0.57 & 0.61 & 0.70 & 0.69 & 0.52 \\
\hline M26 & 1.18 & -0.56 & 0.67 & 0.86 & 1.08 & 1.35 & 0.11 & 1.13 & 1.34 & 1.30 & 1.32 & 1.30 \\
\hline M27 & 1.03 & 0.74 & 0.33 & 1.15 & 1.01 & 0.84 & 0.98 & 0.45 & 0.85 & 0.96 & 0.81 & 0.97 \\
\hline $\mathrm{O} 28$ & -1.14 & -0.26 & -0.18 & -1.10 & -1.07 & -0.88 & -0.84 & -0.52 & -0.89 & -1.03 & -0.89 & -0.98 \\
\hline M29 & -0.33 & 0.97 & 2.67 & -0.11 & -0.02 & 1.38 & -1.00 & 1.48 & 1.35 & 0.64 & 1.06 & 1.26 \\
\hline Mean & 0.00 & 0.00 & 0.00 & 0.00 & 0.00 & 0.00 & 0.00 & 0.00 & 0.00 & 0.00 & 0.00 & 0.00 \\
\hline & & & & & & & & & & & & Contin \\
\hline
\end{tabular}




$\mathbf{G Y} *$
$\mathbf{P}_{\mathbf{N}}$
1.46

$\mathbf{G Y}^{*}$
$\mathbf{G}_{\mathrm{S}}$
1.26

$\begin{array}{lll} & \text { GY* } & \text { GY* } \\ \text { NGP }\end{array}$

$\begin{array}{llll}\mathrm{M} 2 & 1.70 & 1.33 & 1.53 \\ \mathrm{M} 3 & 0.67 & 0.56 & 0.64 \\ \mathrm{M} & 0.61 & 0.40 & 0.45\end{array}$

$\begin{array}{lll}\mathrm{M} 3 & 0.61 & -0.04\end{array}$

$\begin{array}{lll}05 & -0.29 & -1.3 \\ + & \text { O6 } & -1.22\end{array}$

$\begin{array}{lll}1.46 & 1.26 & 1.43 \\ 0.63 & 0.58 & 0.63 \\ 0.49 & 0.50 & 0.51\end{array}$

$\begin{array}{lll}1.46 & 1.26 & 1.43 \\ 0.63 & 0.58 & 0.63 \\ 0.49 & 0.50 & 0.51\end{array}$

0.

1.39

M10 - -0.31

$\begin{array}{ll}\text { M10 } & 0.30 \\ \text { M11 } & 0.74\end{array}$

$\begin{array}{lrr}\mathrm{M} 11 & 0.74 & 0.7 \\ \mathrm{O} 12 & -0.72 & -0.4 \\ \mathrm{O} 13 & 0.03 & -0.0\end{array}$

$\begin{array}{rrr}013 & 0.03 & -0.07 \\ 014 & -0.70 & -0.12\end{array}$

\begin{tabular}{|c|c|c|c|c|c|c|c|c|c|c|c|}
\hline O14 & -0.70 & -0.12 & -0.13 & -0.30 & -0.48 & -0.39 & -0.35 & -0.35 & -0.08 & -0.28 & -0.19 \\
\hline M15 & -0.31 & -0.08 & -0.11 & -0.03 & 0.08 & 0.00 & 0.03 & 0.02 & 0.10 & 0.05 & 0.00 \\
\hline O16 & 0.72 & 0.83 & 0.93 & 0.87 & 0.72 & 0.83 & 0.83 & 0.84 & 0.91 & 0.86 & 0.77 \\
\hline O17 & -1.38 & -1.33 & -1.49 & -1.52 & -1.47 & -1.54 & -1.54 & -1.54 & -1.54 & -1.54 & -1.32 \\
\hline O18 & -0.66 & -0.66 & -0.75 & -0.70 & -0.58 & -0.67 & -0.66 & -0.67 & -0.69 & -0.68 & -0.61 \\
\hline O19 & -1.20 & -1.19 & -1.34 & -1.31 & -1.18 & -1.30 & -1.29 & -1.29 & -1.32 & -1.31 & -1.14 \\
\hline $\mathrm{O} 20$ & -1.09 & -0.94 & -1.05 & -1.13 & -1.15 & -1.17 & -1.16 & -1.16 & -1.11 & -1.15 & -0.97 \\
\hline $\mathrm{O} 21$ & -0.69 & -0.77 & -0.87 & -0.84 & -0.76 & -0.83 & -0.83 & -0.84 & -0.90 & -0.85 & -0.75 \\
\hline $\mathrm{O} 22$ & -0.77 & -0.69 & -0.76 & -0.83 & -0.86 & -0.86 & -0.86 & -0.86 & -0.83 & -0.85 & -0.71 \\
\hline M23 & 1.26 & 1.19 & 1.31 & 1.48 & 1.61 & 1.57 & 1.58 & 1.57 & 1.54 & 1.57 & 1.29 \\
\hline M24 & 1.93 & 1.43 & 1.61 & 1.76 & 1.82 & 1.84 & 1.81 & 1.81 & 1.61 & 1.76 & 1.47 \\
\hline M25 & 0.75 & 0.37 & 0.42 & 0.53 & 0.62 & 0.58 & 0.56 & 0.56 & 0.39 & 0.52 & 0.41 \\
\hline M26 & 1.40 & 1.07 & 1.21 & 1.27 & 1.25 & 1.31 & 1.28 & 1.28 & 1.16 & 1.26 & 1.07 \\
\hline M27 & 0.84 & 0.92 & 1.03 & 1.04 & 1.00 & 1.05 & 1.06 & 1.06 & 1.11 & 1.08 & 0.92 \\
\hline $\mathrm{O} 28$ & -0.93 & -0.89 & -1.00 & -1.05 & -1.05 & -1.07 & -1.07 & -1.07 & -1.07 & -1.08 & -0.91 \\
\hline M29 & 1.07 & 1.02 & 1.18 & 0.98 & 0.65 & 0.88 & 0.85 & 0.87 & 0.91 & 0.88 & 0.85 \\
\hline Mean & 0.00 & 0.00 & 0.00 & 0.00 & 0.00 & 0.00 & 0.00 & 0.00 & 0.00 & 0.00 & - \\
\hline
\end{tabular}

${ }^{1} \mathrm{GY}$ combined with the other traits in different ways, according to the ideal combination of traits, for example: GY*BY, where GY values were multiplied by BY; ${ }^{2} \mathrm{GY}() \mathrm{FPH}$, where a central value is considered as optimal; ${ }^{3} \mathrm{GY} / \mathrm{SY}$, where GY was divided by SY. Trait codes: GY: grain yield; BY: biological yield; SY: straw yield; FPH: first pod height; NNP: number nodes per plant; NPP: number of pods per plant; HI: harvest index; PH: plant height; LOD: lodging; DTF: days to flowering; DFM: days flowering-Maturation; DTM: days to maturity; R/V: reproductive - vegetative ratio; TGW: thousand grain

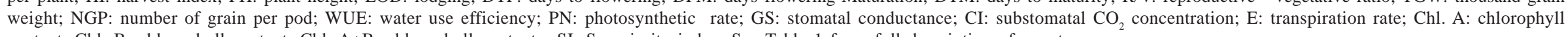
content; Chl. B: chlorophyll content; Chl. A+B: chlorophyll contente; SI: Superiority index. See Table 1 for a full description of genotypes. 
GY was positively correlated with BY, FPH, NPP, HI, $\mathrm{R} / \mathrm{V}, \mathrm{NGP}, \mathrm{P}_{\mathrm{N}}, E$, and Chl.A, Chl.B and Chl.A+B (Figure 3). This indicates that higher values for these traits help to improve GY. Otherwise, traits PH, Lod, DTF and DTM are negative related with GY, where lower values are desirable to improve GY.

A minimum number of traits may be evaluated by soybean breeding programs. Among these traits are: GY, $\mathrm{HI}, \mathrm{NPP}, \mathrm{R} / \mathrm{V}, \mathrm{P}_{\mathrm{N}}$ and $E$. $\mathrm{HI}$ is related to grain yield and biomass production, through the traits GY, BY and SY (Figure 3). HI shows similar correlations to those obtained by GY for the remaining traits and has even more negative correlation with DTM than GY/DTM. In addition, it has a higher correlation with NGP than GY*NGP and is the only trait showed a positive correlation with the yield component TGW. NPP consists of one of the major yield components and is correlated to NNP. Already, R/V is a trait which encompasses in all crop cycle traits, i.e., DTF, DFM and DTM. Physiological traits $\mathrm{P}_{\mathrm{N}}$ and $E$ indicate the capacity of photoassimilates production, maintenance of the metabolic processes and are determinant traits in water use by plants, through WUE trait. In addition, these traits show a high correlation with all chlorophyll indexes (Chl. A, Chl. B and Chl. A+ B).

\section{DISCUSSION}

The main trait improved by soybean breeding companies is GY. In Brazil, the annual genetic gain was in order of $39 \mathrm{~kg} \mathrm{ha}^{-1} \mathrm{yr}^{-1}$ (Todeschini et al., 2019). The GY is selected per se many times. However, an indirect selection is realized for many traits along the breeding process. Many traits need to be increased such as TGW, and others need to be reduced, e.g., lodging. A third group of traits need be in an ideal value, not very high nor very low, e.g., FPH and PH.

The modern genotypes M24 (2011), M23 (2010) and M1 (2007) may be considered the best genotypes, each with specific positive $\mathrm{GY} *$ traits associations. In the other hand, old genotypes, i.e., O17 (1965) and O6 (1979), were the worst genotypes in GYT biplot. In addition, M15 (2003) is exactly the "average genotype" between old and modern genotypes, with a $\mathrm{SI}=0.00$. These results corroborate to Todeschini et al. (2019), that evaluated the same set of soybean genotype performance, and a revealed positive genetic progress of $2.4 \%$ year $^{-1}$.

The M24 had high values for many traits, especially for physiological traits. The increment of $\mathrm{P}_{\mathrm{N}}$ consist in the increase of assimilation rate of $\mathrm{CO}_{2}$, which increases the amount of photoassimilates and, consequently, growth

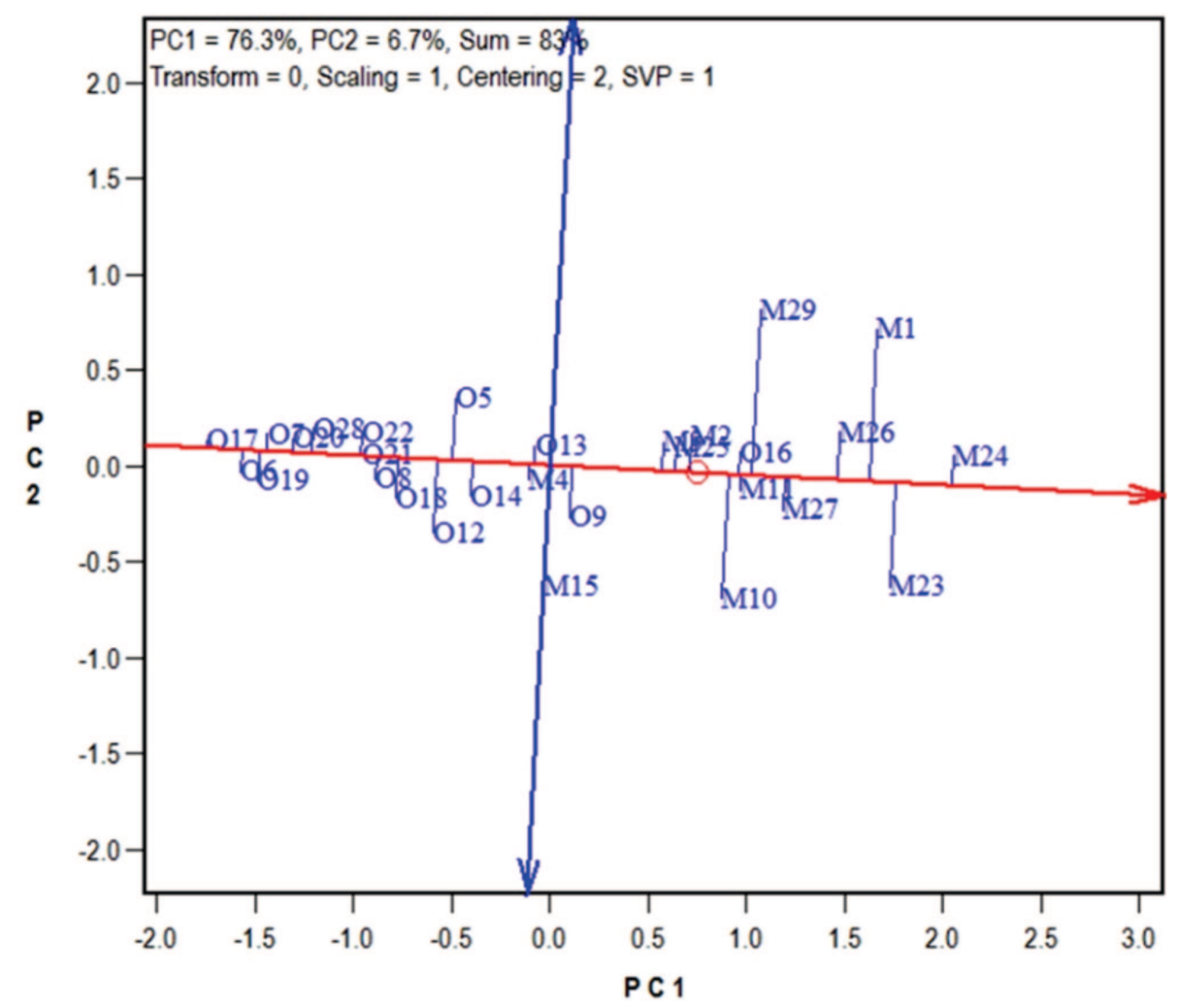

Figure 2: Average tester coordination for 29 Brazilian soybean cultivars released between 1965 and 2011, evaluated for grain yield, agronomic and physiological traits, in two locations in the 2016/17 crop season. Average of the genotype by grain yield*trait (GYT) biplot to rank the genotypes based on their overall superiority and stability of genotypes. The biplot was based on singular value decomposition of the standardized GYT table ("Scaling = 1, Centering = 2"). The genotype focused singular value partition ("SVP $=1$ ”) was used. See Table 1 for a full description of genotypes. 
and GY (Rao \& Chaitanya, 2016; Müller et al., 2017). According to Morrison et al. (1999), the increase of $\mathrm{P}_{\mathrm{N}}$ in the modern genotypes occurs due to reduction in leaf area and the increase in photoassimilates demand. Leaf area reduction together with architecture modification provides greater interception of the photosynthetically active radiation (PAR) on vegetative canopy. Thus, more efficient photosynthetic soybean genotypes present a higher number of fertile nodes in the lower third of plant, resulting GY increase (Müller et al., 2017).

Transpiration rate $(\mathrm{E})$ is positively associated with $\mathrm{GY}$, and most productive genotypes present the higher transpiration rates (Figure 1, Figure 3 ). $\mathrm{G}_{\mathrm{S}}$ consists of the rate of passage of $\mathrm{CO}_{2}$ entering the leaf stomata. A large $\mathrm{G}_{\mathrm{S}}$ can correlate with improved crop yield (Prashar et al.,
2013). Liu et al. (2012) observed a significant increase in $\mathrm{G}_{\mathrm{S}}$ over the years. According to these authors, genotypes increased $\mathrm{P}_{\mathrm{N}}, \mathrm{G}_{\mathrm{S}}$ and $E$ through the release year, and the selection for high-yielding genotypes led to higher photosynthetic ability. In relation to WUE, M24, M23 and M1 presented positive values for this trait.

Increased WUE can improve productivity and reduce water stress under drier environmental conditions (Han et al., 2013; Franks et al., 2015). In thermal and/or drought stress conditions, response mechanism is started involving stomata regulation. In this process, stomata are fast closed in stresses conditions, to reduce water losses by plant (Reynolds-Henne et al., 2010). Battisti et al. (2017) evaluating soybean yield under climate changes in Southern Brazil, observed that reduction of transpiration

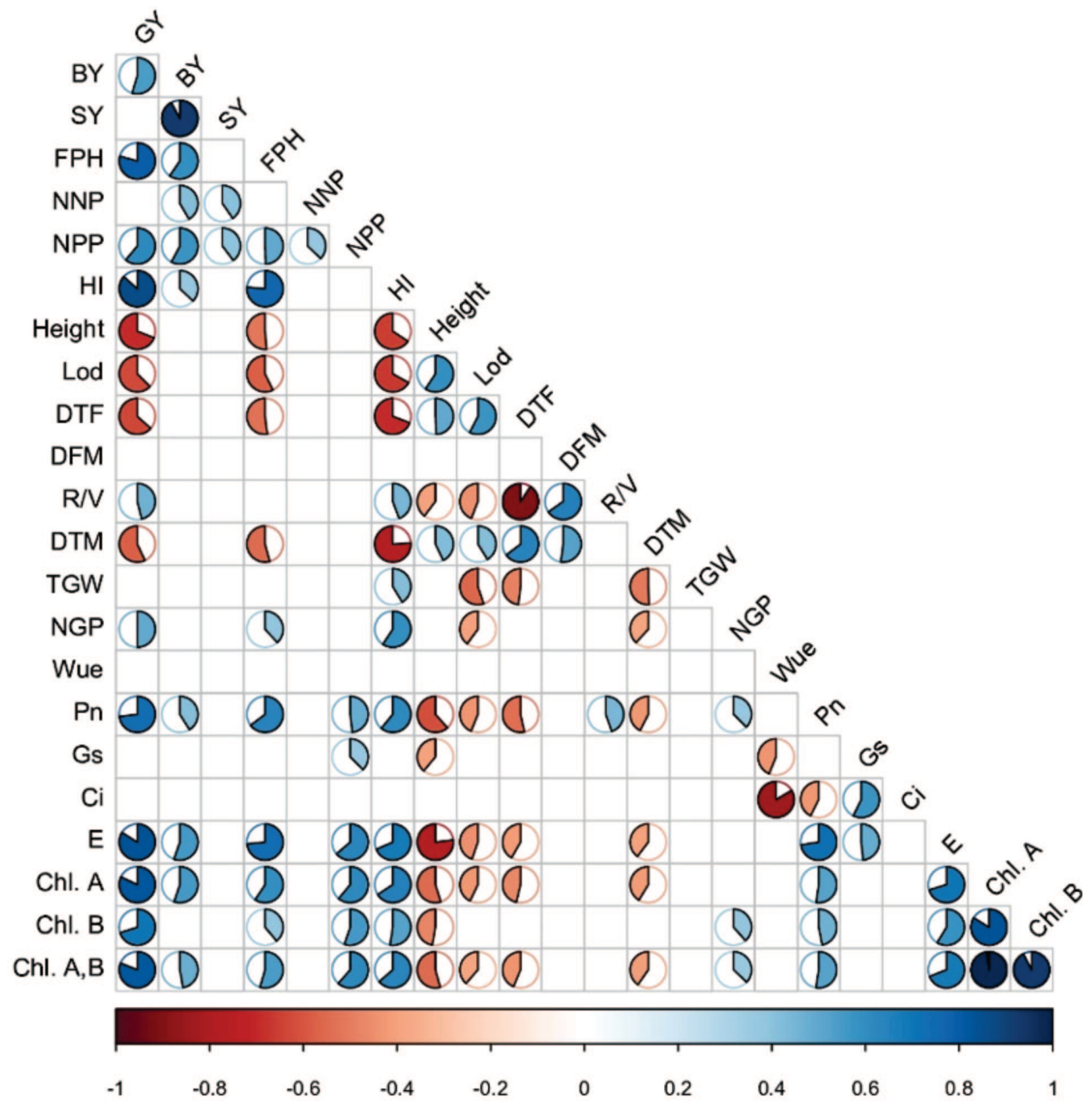

Figure 3: Pearson correlations between 29 Brazilian soybean cultivars released between 1965 and 2011, evaluated for grain yield, agronomic and physiological traits, in two locations in the 2016/17 crop season. Correlations shown are significant $(P<0.05)$ according to the t-test. Trait codes: GY: grain yield; BY: biological yield; SY: straw yield; FPH: first pod height; NNP: number nodes per plant; NPP: number of pods per plant; HI: harvest index; PH: plant height; LOD: lodging; DTF: days to flowering; DFM: days flowering-Maturation; DTM: days to maturity; R/V: reproductive - vegetative ratio; TGW: thousand grain weight; NGP: number of grain per pod; WUE: water use efficiency; $\mathrm{P}_{\mathrm{N}}$ : photosynthetic rate; $\mathrm{G}_{\mathrm{S}}$ : stomatal conductance; $\mathrm{C}_{\mathrm{I}}$ : substomatal $\mathrm{CO}_{2}$ concentration; $E$ : transpiration rate; Chl. A: chlorophyll A content; Chl. B: chlorophyll B content; Chl. A+B: chlorophyll A+B content. 
index collaborates with tolerance induction to drought stress and reduces cultivar sensibility. Thus, WUE increase may be related to how modern genotypes keep metabolism in stress conditions (Blum, 2009).

M24 genotype had high values for R/V ratio and GY/ DTM, two important traits in soybean breeding. A large $\mathrm{R} / \mathrm{V}$ ratio is desirable, since genotypes with a longer reproductive stage have more time for grain filling grains and pod development. Although, a low DTM is desirable because genotypes with a shorter life cycle reduces the incidence of pest attacks and allows, in Brazil and tropical regions, the cultivation of a second crop in the same crop season. Bodner et al. (2018) highlighted the best yielding genotypes to faba bean, belong to the same family of soybean, include phenological pattern combining earliness with prolonged duration of reproductive period. Xavier et al. (2017) conclude that optimal soybean grain yield occurs when growing environment favors faster canopy closure and extend reproductive length.

GY is arguably the most important trait in soybean crop. Except for soybean for specific purposes (like as human food), selection methods and indices are valid only if they give GY its proper importance. The standardized multiple selection index (SMSI), proposed by Gesteira et al. (2018), considers each trait individually, i.e., do not contrast each evaluated trait with GY. These authors evaluated 39 soybean inbred lines and four traits (grain yield, absolute maturity, protein and oil contents). This index indicated a line as the most prominent by SMSI, i.e., associated with early cycle, good yield and grain quality (high oil and protein contents). However, when evaluated at ten locations for two years, this inbred line presented a GY near 3,500 $\mathrm{kg} \mathrm{ha}^{-1}$. This line was preferred over another inbred line with produced near $4,500 \mathrm{~kg} \mathrm{ha}^{-1}$. These results can be misleading in plant breeding since GY is the most important trait. Otherwise, the Superiority Index avoid this mistake, once "genotypes are evaluated by their levels in combining yield with other traits as opposed to by their levels in individual traits" (Yan \& Frégeau-Reid, 2008).

M24, M1 and M23 genotypes highlighted to specific group of traits. In this way, the next step in soybean breeding is to seek the union of all the favorable traits into a single genotype. Among the main practical information presented in this article, it is that soybean breeding companies may evaluate set of core traits (GY, $\mathrm{HI}, \mathrm{NPP}, \mathrm{R} / \mathrm{V}, \mathrm{P}_{\mathrm{N}}$ and $E$ ) in their germplasm bank and identify strengths and weaknesses of each genotype. Subsequently, crosses for new lineages development may be schematized to join the strengths of each parent in a single genotype.

Positive correlation between chlorophyll content and grain yield is showed in cultivated plants as soybean (Ergo et al., 2018, Sakowska et al., 2018), wheat, barley, and oat (Sid'Ko et al., 2017). Ergo et al. (2018) studying heat and drought stressed field-grown soybean, reveled thought principal component analysis complemented with multiple regression models that physiological and biochemical traits may be include as powerful explanatory variables of yield.

Over the years, soybean breeding aimed to get an optimal combination of morphological and physiological traits that results in an efficient plant material, known as the ideotype by (Martre et al., 2015). Researches about traits association certainly helped to obtain the ideotype and genetic progress. Cui et al. (2015) reported increase in GY by increase in number of grains per pod. Regarding to physiological traits, over more than 80 years of breeding, Koester et al. (2014); Koester et al. (2016) showed positive linear association of light interception, energy conversion with increase in grain yield gains. Also, the modern lines presented lodging resistance that is related to radiation use efficiency and yield potential (Koester et al., 2014; Rogers et al., 2014), that corroborate to results of this study and show the traits association importance to soybean breeding.

\section{CONCLUSIONS}

1. Soybean breeding improved desirable traits in brazilian cultivars.

2. Some cultivars present interesting sets of favorable traits: DMario 58i,TMG 7161RR TMG 7262.

3. Grain yield, Harvest index, number of pods per plant, the ratio between reproductive and vegetative period, photosynthetic rate and transpiration rate are core traits which can be evaluated in soybean breeding to obtain future gains.

\section{ACKNOWLEDGMENTS}

To Coordenação de Aperfeiçoamento de Pessoal de Nível Superior (CAPES) for granting the masters and doctoral scholarships.

\section{CONFLICT OF INTEREST}

The authors declare no conflict of interest.

\section{REFERENCES}

Alvares CA, Stape JL, Sentelhas PC, Moraes G, Leonardo J \& Sparovek G (2013) Köppen's climate classification map for Brazil. Meteorolgische Zeitschrift, 22:711-728.

Battisti R, Sentelhas PC, Boote KJ, Câmara GMS, Farias JRB \& Basso CJ (2017) Assessment of soybean yield with altered waterrelated genetic improvement traits under climate change in Southern Brazil. European Journal of Agronomy, 83:01-14.

Blum A (2009) Effective use of water (EUW) and not water-use efficiency (WUE) is the target of crop yield improvement under drought stress. Field Crops Research, 112:119-123. 
Bodner G, Kronberga A, Lepse L, Olle M, Vågen IM, Rabante L, Fernández JA, Ntatsi G, Balliu A \& Rewald B (2018) Trait identification of faba bean ideotypes for Northern European environments. European Journal of Agronomy, 96:01-12.

Cruz CD, Regazzi AJ \& Carneiro PCS (2012) Modelos biométricos aplicados ao melhoramento genético. $3^{\mathrm{a}}$ ed. Viçosa, Universidade Federal de Viçosa. 668p.

Cui X, Dong Y, Gi P, Wang H, Xu K \& Zhang Z (2015) Relationship between root vigour, photosynthesis and biomass in soybean cultivars during 87 years of genetic improvement in the northern China. Photosynthetica, 54:81-86.

Ergo VV, Lascano R, Vega CR, Parola R \& Carrera CS (2018) Heat and water stressed field-grown soybean: a multivariate study on the relationship between physiological-biochemical traits and yield. Environmental and Experimental Botany, 148:01-11.

Franks PJ, Doheny-Adams TW, Britton-Harper ZJ \& Gray JE (2015) Increasing water use efficiency directly through genetic manipulation of stomatal density. New Phytologist, 207:188195.

Fehr WR \& Caviness CE (1977) Stages of Soybean development. Available at: <https://pdfs.semanticscholar.org/ba57/ a53c2d3fae2d4665f17ddfa4a88ad573e0db.pdf $>$. Accessed on: August $20^{\text {th }}, 2018$.

Gesteira GS, Bruzi AT, Zito RK, Fronza V \& Arantes NE (2018) Selection of early soybean inbred lines using multiple indices. Crop Science, 58:2494-2502.

Han X, Tang S, An Y, Zheng DC, Xia XL \& Yin WL (2013) Overexpression of the poplar NF YB7 transcription factor confers drought tolerance and improves water-use efficiency in Arabidopsis. Journal of Experimental Botany, 64:4589-4601.

Koester RP, Skoneczka JA, Cary TR, Diers BW \& Ainsworth EA (2014) Historical gains in soybean (Glycine max Merr.) seed yield are driven by linear increases in light interception, energy conversion, and partitioning efficiencies. Journal of Experimental Botany, 65:3311-3321.

Koester RP, Nohl BM, Diers BW \& Ainsworth EA (2016) Has photosynthetic capacity increased with 80 years of soybean breeding? An examination of historical soybean cultivars. Plant, Cell \& Environment, 39:1058-1067.

Liu G, Yang C, Xu K, Zhang Z, Li D, Wu Z \& Chen Z (2012) Development of yield and some photosynthetic characteristics during 82 years of genetic improvement of soybean genotypes in northeast China. Australian Journal of Crop Science, 6:14161422 .

Martre P, Quilot-Turion B, Luquet D, Ould-Sidi Memmah MM, Chenu K \& Debaeke P (2015) Model-assisted phenotyping and ideotype design. Crop Physiology, 2:349-373.

Mendiburu F (2017) Agricolae: Statistical procedures for agricultural research. $\mathrm{R}$ package version 1.2-8. Available at: <https://cran.r-project.org/web/packages/agricolae/index.html>. Accessed on: July 18, 2018.

Morrison MJ, Voldeng HD \& Cober ER (1999) Physiological changes from 58 years of genetic improvement of short-season soybean cultivars in Canada. Agronomy Journal, 91:685-689.

Müller M, Rakocevic M, Caverzan A \& Chavarria G (2017) Grain yield differences of soybean cultivars due to solar radiation interception. American Journal of Plant Sciences, 8:2795-2810.
Oliveira ACB \& Rosa APSA (2014) Indicações técnicas para a cultura da soja no Rio Grande do Sul e em Santa Catarina, safras 2014/2015 e 2015/2016. Pelotas, Embrapa Clima Temperado. $124 \mathrm{p}$.

Paula RC, Pires IE, Borges RCG \& Cruz CD (2002) Predição de ganhos genéticos em melhoramento florestal. Pesquisa Agropecuária Brasileira, 37:159-165.

Prashar A, Yildiz J, Mcnicol JW, Bryan GJ \& Jones HG (2013) Infra-red thermography for high throughput field phenotyping in Solanum tuberosum. PLoS ONE, 8:01-09.

Rao DE \& Chaitanya KV (2016) Photosynthesis and antioxidative defense mechanisms in deciphering drought stress tolerance of crop plants. Biologia Plantarum, 60:201-218.

Reynolds-Henne CE, Langenegger A, Mani J, Schenk N, Zumsteg A \& Feller U (2010) Interactions between temperature, drought and stomatal opening in legumes. Environmental and Experimental Botany, 68:37-43.

Rogers J, Chen P, Shi A, Zhang B, Scaboo A, Smith SF \& Zeng A (2014) Agronomic performance and genetic progress of selected historical soybean varieties in the southern USA. Plant Breeding, 134:85-93.

Sakowska K, Albert G, Genesio L, Peressotti A, Delle Vedove G, Gianelle D, Colombo R, Rodeghiero M, Panigada C, Juszczak R, Clesti M, Rossini M, Haworth M, Campbell BW, Mevy JP, Vescovo L, Cendrero_mateo MP, Rascher U \& Miglietta F (2018) Leaf and canopy photosynthesis of a chlorophyll deficient soybean mutant. Plant, Cell \& Environment, 41:1427-1437.

Santos RD, Lemos RC, Santos HG, Ker JC, Anjos LHC \& Shimizu SH (2013) Manual de descrição e coleta de solo no campo. Viçosa, Sociedade Brasileira de Ciência do Solo. 100p.

Sharifi P \& Ebadi AA (2018) Relationships of rice yield and quality based on genotype by trait (GT) biplot. Anais da Academia Brasileira de Ciências, 90:343-356.

Sid'Ko AF, Botvich IY, Pis'Man TI \& Shevyrnogov AP (2017) Estimation of the chlorophyll content and yield of grain crops via their chlorophyll potential. Biophysics, 62:456-459.

Todeschini MH, Milioli AS, Rosa AC, Dallacorte LV, Panho MC, Marchese JA \& Benin G (2019) Soybean genetic progress in South Brazil: physiological, phenological and agronomic traits. Euphytica, 215:01-12.

Xavier A, Hall B, Casteel S, Muir W \& Rainey KM (2017) Using unsupervised learning techniques to assess interactions among complex traits in soybeans. Euphytica, 213:01-18.

Yan W (2001) GGEbiplot - A Windows application for graphical analysis of multienvironment trial data and other types of twoway data. Agronomy Journal, 93:1111-1118.

Yan W \& Frégeau- Reid J (2008) Breeding line selection based on multiple traits. Crop Science, 48:417-423.

Zhang H, Hao D, Sitoe HM, Yin Z, Hu Z, Zhang G \& Yu D (2015) Genetic dissection of the relationship between plant architecture and yield component traits in soybean (Glycine max) by association analysis across multiple environments. Plant Breeding, 134:564-572. 